\title{
SCHOOL ADMINISTRATORS' PREPARATION, CHALLENGES, AND COPING MECHANISM IN THE IMPLEMENTATION OF BRIGADA ESKWELA IN THE NEW NORMAL
}

\author{
Reynaldo F. Manila ${ }^{1}$, Ronald S. Decano ${ }^{2}$ \\ ${ }^{1}$ Graduate Student, Doctor of Philosophy in Educational Management, Davao del Norte State College \\ ${ }^{2}$ Dean, Institute of Advanced Studies, Davao del Norte State College
}

Article DOI: https://doi.org/10.36713/epra9298

DOI No: 10.36713/epra9298

\begin{abstract}
During the COVID-19 pandemic, education changed dramatically, notably in school-community engagement. School administrators prepared for and implemented the novel adopt-a-school program, Brigada Eskwela, by adopting the Department's Basic Education Learning Continuity Plan. This program is feasible but not without difficulties. As a result, this phenomenological research examined Cluster IV secondary and integrated school administrators' experiences in the Division of Davao City implementing the adopt-a-school program: Brigada Eskwela in the new normal. The researcher selected the participants via purposive sampling through remote physical and video conferencing of one-on-one in-depth interviews. The findings revealed that school administrators prepared for the transition of the adopt-a-school program: Brigada Eskwela, including overcoming challenges and developing coping mechanisms in the face of the new normal. Collaboration and partnership programs of stakeholders and private partners will address their resources and training needs to manage the school effectively for improved student learning outcomes. It is truly a community for students' new normal education.
\end{abstract}

KEYWORDS: Phenomenological research, Cluster IV secondary, and integrated school administrators, experiences, implementation, adopt-a-school program: Brigada Eskwela

\section{INTRODUCTION}

From the global perspective, public-private partnerships through adopt-a-school program become a game-changer and are very instrumental in providing assistance and assistance to the public schools in support packages such as infrastructure and physical facilities, training and development of teachers, a feeding program for students, stipends, scholarship programs among other assistance for the education of students, particularly in the least developed countries.

Recent controversy has revealed that governments face significant educational obstacles, particularly those in developing countries. According to the United Nations, around 115 million children are out of school, with most of these children residing in Sub-Saharan Africa and South Asia (United Nations 2005). While progress toward achieving the Millennium Development Goals for education (or MDG's for short), much more work remains. As LaRocque (2008) points out, this is especially true in the least developed countries.

Apart from a lack of access to education, the low quality of education offered means that the majority of students who graduate primary school in underdeveloped nations find themselves unprepared for the world of work. Today, education in the developing world has the dual problems of increasing enrollment and retention of children in school while also improving learning results, as LaRocque (2008) underlined. 
More importantly, many governments have responded to these education challenges by making greater use of the private sector and public-private partnerships (PPP's) in education as a means of improving both the delivery and financing of Basic Education in developing and developed countries.

In Africa, the Adopt-A-School Foundation is a registered section 21 company based in Johannesburg, South Africa. The principal aim of the foundation is to encourage and mobilize individuals and companies to adopt schools. The project's primary focus is to support creating and enhancing conducive learning and teaching environment (Adopt-a-School Foundation, 2015).

Based on volunteerism and multiple partnerships, the Adopt-A-School Program (ASP), specifically Brigada Eskwela of the Department of Education (DepEd) the Philippines, provides an opportunity for school-community stakeholders and the private sector to work collaboratively toward the noble goal of educating all Filipinos (Llego, 2020).

The school administrators' initiative and concerted efforts engage all concerned stakeholders and parties in developing a sense of ownership in seeking private partners and presenting them with priority improvement areas based on good and quality data. These are all appreciated due to assistance and rendered services extended to the schools in supporting the implementation of the Basic Education Learning Continuity Plan (for brevity BE-LCP) School Year 2020-2021. BE-LCP is a package of education interventions that will respond to fundamental education challenges brought about by the COVID-19 pandemic (DepEd Order No. 12, 2020).

In the COVID-19 pandemic, all sectors and industries in the international community like the nongovernment organizations, charitable institutions, and private sector organizations had been affected drastically. They are actively involved in the Adopt-A-School Program, which will face challenges in some areas of their deliverables due to the globally implemented health standard protocols.

Specifically, due to one of the world's emerging public health emergencies, the COVID-19 pandemic caused by the Novel Coronavirus SARS-COV-2, this Adopt-A-School Program, particularly Brigada Eskwela, has been significantly impacted. The program is quite difficult to fully implement to combat COVID-19 threats, which draw massive global attention and awareness to the issue of eradicating growing infections (Guo et al., 2020).

The Philippines was declared a state of calamity by Presidential Proclamation No. 929 s. 2020. Suspending and temporarily ceasing businesses, enterprises, and business operations have resulted in a near-complete halt to the execution of school programs. As a result, education is one of the sectors most adversely affected by the COVID-19 pandemic (De Villa, J.A., Manalo, F.K.M., 2020).

Schools have become the most vulnerable to safety and security threats, especially in Davao Region, where COVID-19 positive cases have reached an all-time high. As a result, the Department will implement alternative modes of instruction, most notably modular distance learning, based on a survey of Cluster IV secondary and integrated schools. At the same time, face-to-face will remain suspended per public health protocol and existing city ordinances.

The practice of Brigada Eskwela is no longer in the traditional sense, which entails physical cleaning, painting, repainting, and other minor repairs. Unless another DepEd issuance specifies otherwise, the implementation of the said program continues during the two weeks preceding the start of classes in public schools, subject to the current local risk classification and community quarantine guidelines (DepEd Memorandum No. 53, s. 2020).

Brigada Eskwela's new model focuses on preparations and establishing partnerships to ensure that learning continues even during COVID-19. The events highlight collaborative efforts that support the Department's efforts to secure the continuation of high-quality basic education in the face of COVID-19's challenges and to execute the BELCP (DepEd Memorandum No. 53, s. 2020).

The Department advises school administrators to have the virtual platform online watch party for information drive to all stakeholders and private partners that schools are open for Brigada Eskwela.

In addition, school administrators in the new normal School Year 2020 - 2021 find a hard time preparing for the targeted Adopt-A-School Progam, particularly Brigada Eskwela in the field office. In the advent of using new technologies, for example, online platforms in advocacy and information drive campaigns, that is something strange for school administrators to communicate to identified partners and stakeholders in the hinterlands. Initially, communication letters are delivered and sent to the partners and other stakeholders for possible assistance and services as distributed before the declaration of this pandemic. 
On the other hand, the identified private partners and other stakeholders face barriers due to strict health protocols. They are hesitant in extending assistance and services for their safety and security, and the uncertainty that the pandemic has brought to their businesses or sources of income.

As a result, administrators face many challenges, including significant adjustments to the strategies and actions in sourcing out. Also, they have issues following up on additional assistance and services from partners and other stakeholders in the said program in Davao City's Cluster IV Secondary and Integrated Schools Division in the remote Paquibato District of Davao City, Philippines.

As to the implementation of the Adopt-A-School Program, particularly Brigada Eskwela supporting modular distance learning in the new normal, school administrators have experienced a significantly different lifestyle from previous normal school years, which researchers should have thoroughly explored for study. This event calls for special attention to the researcher to conduct further study to contribute a piece of research work to school administrators and concerned stakeholders that redounds to the benefit of the learners and communities.

This study explored the secondary and integrated school administrators' experiences implementing the Adopt-A-School Program, particularly Brigada Eskwela, in the new normal. Furthermore, it sought to investigate the school administrators' preparation, challenges, and coping mechanisms in said program.

\section{Research Design}

\section{METHODOLOGY}

This study used a descriptive phenomenological approach as its research design that focused on investigating the experiences of Cluster IV secondary and integrated school administrators in implementing the Adopt-A-School Program (for brevity ASP), particularly Brigada Eskwela in the new normal. The compilation was through bibliographic and field research. This type of research was qualitative - a collection of data that utilized in-depth interviews, observation of participants, and documentation. The consideration of participants' availability and convenience became the basis when scheduling the interview. The actual one-on-one, in-depth interview at an average of 30 minutes took place through distant physical and video conferences. The utilization of open-ended questions enabled the participants to answer in their own words. The approval of the participants resulted in the recording of the conversations. The interviews were documented verbatim in the transcripts. Cold and warm analyses guided the data treatment. The cool analysis included the participants' statements, phrases, and sentences pertinent to the encountered phenomenon. These served as the foundation for conducting a warm analysis as clustered and classified data. The highlighted terms elicited the emergence of themes.

\section{Design and Procedure}

This study was qualitative research that combined theoretical and empirical research to describe and clarify human experience as it appears in people's lives. Qualitative data were gathered primarily in spoken or written language rather than numerical form. Possible data sources were interviews with participants, observations, and documentation. Typically, the process of data into written text for analytic purposes matters. In simple terms, phenomenology is a method of research that aims to capture the essence of a phenomenon by examining it through the eyes of those who have encountered it.

\section{Participants and Sampling}

The study participants were eight school administrators from the public Cluster IV secondary and integrated schools in the Division of Davao City, chosen through purposive sampling. Purposive sampling for the homogenous case was appropriate because it focuses, reduces variation, simplifies analysis, and facilitates group interviewing (Patton, 1990).

These administrators were the sources of first-hand information as supporting evidence to ascertain the preparation, challenges, and coping mechanisms in implementing the Adopt-A-School Program, particularly Brigada Eskwela in the new normal.

\section{Role of the Researcher}

In the conduct of this study, the researcher took the role of gathering data from the identified informants. The study employed personal interviewing, analysis, and verification. The informants' selection was purposive, which means the primary consideration was to select administrators managing secondary and integrated schools in the boondocks of Malabog-Paquibato areas Davao City. The study targeted them in getting substantial, reliable, and valid 
information. After selecting the informants, the researcher immediately prepared consent letters to allow him to conduct a personal interview - the set schedules targeted at their most convenient time. In getting vital information, the study focused on the related questions that can support what the researcher wants to gather.

\section{Data Collection Procedure}

The data collection process was as follows:

1. Seeking Permission to Conduct the Study. The researcher wrote a letter to the Office of the Schools Division Superintendent, which was routed through Cluster IV Public Schools District Supervisor of the Department of Education in Davao City. As well as the said letter sent to the school administrators themselves, requesting access to records and personal interviews and discussions with key participants in the study.

2. Conduct of Interview. During the interview, the researcher purposely selected the participants who had first-hand information. The established interview schedules ensure a proper interview and account for the participant's availability and consideration of detailed responses.

\section{RESULTS AND DISCUSSION}

\section{School administrators' preparation in the implementation of Brigada Eskwela}

1.1 Maintaining close contact with external stakeholders and identifying private partners

Community engagement is one of the five strands of Domain 5: Building Connections in the national adoption and implementation of Philippine Professional Standards for School Heads in the Department of Education (DepEd) Philippines (DepEd Order No. 24, s. 2020). Most of the participants believed in the valuable contributions of stakeholders and active participation of private partners in school improvement, particularly in the pursuit of continuing education of learners in the new normal school year 2020 - 2021. Basic Education Learning Continuity Plan (BE-LCP) is a package of education intervention that will respond to basic education challenges brought about by the COVID-19 pandemic (DepEd Order No. 12, s. 2020). School administrators must work side-by-side with the stakeholders such as the Local Government Unit (LGU) officials and employees, the parents and guardians, and identify potential private partners in the boondocks of Malabog-Paquibato areas in Davao City. However, unluckily, there are only a few private partners this pandemic time considering everybody is targeting the survival of both lives and business interests.

\subsection{Communicating with the stakeholders and the private partners and leveraging new technologies}

Most participants shared that constant communication is in written, verbal, phone, and online means with the stakeholders. Besides, the private partners are the winning formula in implementing Adopt-A-School Program: Brigada Eskwela for our most cared students. Effective communication for Brigada Eskwela, a form of partnership, requires consistent follow-ups and updates from the school administrators and their technical working groups to ensure the stakeholders and private partners' positive responses and commitment to extend assistance to the schools in the form of services and donations. Numerous school/family/community partnerships have produced dramatic and lasting increases in student achievement (National School Public Relations Association, 2006).

However, not all participants have set up constant and effective communication with the stakeholders, and the private partners, particularly in the new concept of Brigada Eskwela, to ensure that learning continues even in the time of COVID-19. Generally, the common practice is to deliver the letter of invitation to stakeholders to participate in the annual Brigada Eskwela and or solicitation to source out donations from private partners that is no longer possible for some restrictions implemented by the constituted authorities. Learning to use social media effectively in the current climate can benefit the school's public image, community connections, and students' learning (Sheninger, 2015).

\subsection{Capacity building for continuous professional learning and development}

The advent of using new technologies, such as online platforms in advocacy and information drive campaign of Adopt-A-School Program: Brigada Eskwela, is strange for school administrators to communicate with identified private partners and not so with the stakeholders in the hinterlands is a must. Thus this requires capacity building for continuous professional learning and development. Besides, there are opportunities where the school administrators can practice and experience the teleconferencing with school personnel and fellow school heads in Cluster IV via a virtual meeting in Zoom and or in Google Meet spearheaded by our Public Schools District Supervisor. Additionally, webinars for school administrators on various topics are in place, most notably training needs and 
digital competencies in the new normal. Others are very determined and persevere in watching video tutorials and are mentored by peers. Thus, it is just a matter of versatility in leadership among school leaders becoming responsive and adaptive to the situation through learning and development (Lisud, 2021).

\section{Challenges encountered during the preparation for Brigada Eskwela 2.1 Cluster IV schools' locations}

The participants mentioned that Cluster IV secondary and integrated schools in Malabog-Paquibato areas are the significant challenges in preparing for Adopt-A-School Program, particularly Brigada Eskwela, in the new normal. Aside from the areas considered one of the farthest from downtown Davao City, there are still schools with no roads accessible for four-wheel vehicles. In contrast, others have constructed roads, no power line, no stable communication signal for mobile phones, and internet connectivity. The collective concern of school administrators is that there are only a few private partners that can assist with services and or donations to schools, particularly accessible ones in said areas. The government had only recently cleared areas of terrorist groups affiliated with the New People's Army, with only scattered members to reassert their power and influence. However, community monitoring is very active in putting an end to this terrorist activity in the area. In addition to this, there were recently more newly established secondary and integrated schools in remote villages to counter deceptions of lawless elements and to provide responsive and quality education for our youths. As a result, our stakeholders, particularly in Brigada Eskwela, are highly supportive in implementing the Adopt-A-School Program, providing services such as planning, implementing priority improvement areas, monitoring and evaluating projects, activities, and programs (PAP's). Besides, manual labor for school improvement, commonly called Bayanihan, is also offered for good. However, the COVID-19 pandemic somehow limits the active participation of stakeholders strictly following health standard protocols as implemented by constituted authorities. The COVID-19 pandemic placed the Philippines in a state of calamity under Proclamation No. 929 series 2020, which challenged school administrators. There are many challenges in public schools today; now is the time for educators, parents, and stakeholders to come together and begin to find solutions - for the benefit of all students (Chen, 2020).

\subsection{Difficulty in obtaining resources and assistance}

Another challenge is sourcing out resources and assistance in the form of services and donations during the full implementation of community lockdowns for health standard protocols as experienced by school administrators during Brigada Eskwela in the new normal (Presidential Proclamation No. 929, s. 2020). Most school personnel, including the school administrators, were in alternative work arrangements: three-day onsite duty and two-day workfrom-home scheme (DepEd Order No. 11, s. 2020). As stated previously in the preparations stage, not all participants, specifically school administrators, have established continuous and effective communication with stakeholders and private partners. Moreover, learning and development for the administrators is a must. It follows that obtaining resources and or assistance from targeted private partners is the primary focus. There is a difficulty in the new normal.

\subsection{Forging partnerships}

In this country, public-private partnerships (PPP's) in schools are implementing Adopt-A-School Program as per Republic Act 8525, also known as "Adopt-A-School Act of 1998. The program allows private entities to assist a public school in staff and faculty development for training and further education; construction facilities; upgrading existing facilities; provision of books, publications, and other instructional materials; and modernization of instructional technologies (R.A. No. 8525, 1998). The participants, school administrators per se, are responsible for forging partnerships in the boondocks of Malabog - Paquibato from private entities for school priority improvement areas with insufficient funds for its implementation and not covered by school maintenance and other operating expenses (MOOE). Needless to note, participants had not entirely forged partnerships from private entities for immediate concerns during this pandemic time. That is why the schools were mainly dependent on the technical assistance coming from the Schools Division Office of Davao City, particularly on conducting psychological first aid (PFA) and PFA training, debriefing of learners, among others for good. 


\section{Coping mechanism to address the challenges \\ 1.1 Positive well-being}

The participants' positive well-being significantly alleviates the difficulties of implementing the new normal education, particularly in implementing the Adopt-A-School Program: Brigada Eskwela. Support systems from fellow school administrators in Cluster IV exchanged words of encouragement and motivation as a source of self-confidence, a healthy lifestyle, and stress management, allowing them to pursue and perform their duties and responsibilities despite the numerous challenges of these challenging times. When school administrators foster a positive climate and sense of well-being, they consider environmental factors, social relationships, personal fulfillment, and health factors to improve school performance (Konu, A. and Rimpela, M., 2002).

\subsection{Openness to change}

Change is the only constant in this world. The participants recognized that they must be adaptable and flexible to survive and succeed in daily life. One participant mentioned that school administrators must be willing to unlearn, relearn, and learn new things to maintain their personal and professional growth. Flexibility and adaptability are critical characteristics for school administrators who wish to forge partnerships with external stakeholders and private entities to obtain assistance and address immediate concerns. Effective school administrators will adapt to changing and modifying leadership roles and approaches in response to the schools' context, with the assistance of concerned stakeholders, private partners, and available resources. As administrators, it is also critical to recognize that operating a productive school for students includes developing positive and productive relationships with staff members, teachers, external stakeholders, and private partners (Soper, 2017).

\subsection{Time management}

Time management is critical for carrying out official duties and responsibilities, whether at home or work, and for fully implementing alternative work arrangements (DepEd Order No. 11, s. 2020). Participants stated that time management is critical to meeting deadlines. These enable them to attend school, perform household chores, and recharge their batteries through rest (De Villa, J.A., Manalo, F.K.M., 2020). Setting priorities and adhering to perfect routines and habits consistently enable them to manage their time effectively. Advanced technology has made working much more manageable and superficial, such as teleconferencing with school personnel and stakeholders on critical issues and targets for securing resources and assistance from private partners (Facilities 450mm Consortium, 2021).

\subsection{Supporting system and peer mentoring}

The participants stated that the support system and peer mentoring in Cluster IV secondary and integrated schools is exceptionally active, led by our Public Schools District Supervisor, intending to collaborate and share best practices in the field. They seek guidance and assistance from one another as they prepare the Adopt-A-School: Brigada Eswela and request tools and or pre-made templates for online softcopies of communication for the said program. Mentoring and support are two of the best practices for continuous professional learning and development in Cluster IV schools. School administrators who embrace and lead change adopt a support system and peer mentoring to develop confidence and competence in the new normal. School administrators leverage one another's support as a practical way to stay on track, particularly about identified targets. Additionally, the success of this cluster of schools began with the school administrator establishing a collaborative leadership approach that included coaches, teachers, and other stakeholders (Brooke, 2017).

\subsection{Collaboration and or partnership}

The school must involve all stakeholders, interested parties, and even private entities. A kind of schoolcommunity engagement, collaboration, and partnership supports the adage that it takes a village to educate a child. Thus, education is a shared responsibility shared by schools and the entire community to ensure holistic, inclusive, responsive, and of high quality. DepEd Memorandum No. 53, series 2020 stipulated the Joint Implementing Guidelines on the 2020 Brigada Eskwela and Oplan Balik Eskwela Relative to the COVID-19 Situation and the Adopt-A-School Program established under Republic Act 8525. The school strengthens partnerships to support the Basic Education Learning Continuity Plan (De Villa, J.A., Manalo, F.K.M., 2020). Collaboration and or partnership is a winning formula for significant community engagement. That is sourcing resources and assistance from the stakeholders and the private entities to improve the school. Parents understand their critical role in helping out the 
school sourcing resources supporting modular distance learning. In return, school administrators see that teachers become more responsible in providing quality instruction among their learners. In this case, all concerned parties are actively involved in sourcing resources and or assistance from whoever can provide for higher learning outcomes of the learners. Hence, as Little (2011) emphasized, collaboration and partnership can strengthen, support, and even transform individual partners, resulting in improved program quality, more efficient use of resources, and better alignment of goals and curricula (Harvard Family Research Project, 2010). Mainly, the Adopt-A-School Program: Brigada Eskwela in the new normal is still a success through the concerted efforts in Cluster IV secondary and integrated school administrators.

\section{CONCLUSIONS}

This phenomenological research targeted the Cluster IV secondary and integrated school administrators' experiences implementing the Adopt-A-School Program: Brigada Eskwela in the new normal. Preparation, challenges, and coping mechanism emerged as emerging themes. The findings lead to the following conclusions:

1. Three core themes on preparation came out. These include maintaining close contact with external stakeholders and identifying private partners, communicating with external stakeholders and private partners and leveraging new technologies, and capacity building for continuous professional learning and development. Preparation enables school administrators to plan appropriate actions for the Adopt-A-School Program: Brigada Eskwela's implementation.

2. Three core themes relating to difficulties become evident. These include Cluster IV schools' locations, difficulty obtaining resources and assistance, and forging partnerships. School administrators tasked with implementing the Department's Basic Education Learning Continuity Plan and preparing for Adopt-A-School Program: Brigada Eskwela in the new normal. They face obstacles that could jeopardize the program's success. These obstacles should be recognized and addressed to assist school administrators in mitigating problems and carrying out their responsibilities.

3. Five core themes related to the coping mechanisms were identified. Positive well-being, openness to change, time management, supporting system and peer mentoring, and collaboration and partnership. Though impediments emerged during the Adopt-A-School Program: Brigada Eskwela, school administrators have strategies to overcome the new normal's difficulties. These enable them to meet the demands of the new Adopt-A-School Program: Brigada Eskwela and to carry out their duties and obligations as administrative managers of schools.

\section{ACKNOWLEDGMENT}

With profound gratitude, the researcher expresses his thanks to all those whose hearts, hands, and minds have extended their support to make this study a successful one.

First and foremost, to the dear Almighty Father, the Giver of life, to Whom all honor and glory He offered for the love, strength, wisdom, and blessings to persevere in this quest for the highest educational attainment.

To the panel of examiners chairman for the critique and suggestions to make this study very successful.

To the researcher's professors, for the knowledge they had imparted, which will remain in his mind.

His adviser Ronald S. Decano, Ph.D., for his intellectual generosity and untiring dedication to refining this research is a purposive academic pursuit.

The researcher's wife, Mrs. Maricel Daquio - Manila, MAED, and daughters, Lady Athena Francheszcka D. Manila and Lady Althea Franzhaine D. Manila, for the understanding and moral support they extended.

To the researcher's relatives and friends, for encouraging him to pursue his study values him much.

Special thanks to Dr. Reynaldo M. Guillena, CESO V, Office of the Schools Division Superintendent, Division of Davao City thru Bernabe M. Alicaya, Public Schools District Supervisor, Cluster IV Secondary and Integrated Schools, for their favorable response to conduct this study.

May God shower them with more blessings and happiness to these people behind his success. Thanks, everyone.

\section{REFERENCES}

1. Adopt-a-School Foundation (2015). Non-government Organization (NGO) Based in Johannesburg, South Africa. http://www.ngopulse.org/opportunity/2015/03/30/programme-manager-educationist

2. Adopt-A-School-CONAPAC Peru (2021). What we do, Adopt A School.conapac.org/adopt.html

3. Asia Foundation's Books for Asia Program. 80 Elmira Street, San Francisco, CA 94124 Phone: (415)656-8990 Email: info@asiafound.org 
https://asiafoundation.org/publication/books-for-asia

4. Brooke, E. (2017). Four Key Factors of Effective School Leadership. Lexia Learning. https://www.lexialearning.com/resources/white-papers/four-key-factors-effective-school-leadership

5. Carter N, Bryant-Lukosius D, DiCenso A, Blythe J, Neville AJ. The use of triangulation in qualitative research. Oncol Nurs Forum. 2014 Sep;41(5):545-7. DOI: 10.1188/14.ONF.545-547. PMID: 25158659.

6. Chen, G. (2019). Adopt a Public School: Creating Partnerships that Benefit the Children https://www.publicschoolreview.com/blog/adopt-a-public-school-creating-partnerships-that-benefit-the-children

7. Chen, G. (2020). 10 Major Challenges Facing Public Schools. Public School Review. $2445^{\text {th }}$ Avenue, \# J-229, New York, NY 10001

https://www.publicschoolreview.com/blog/10-major-challenges-facing-public-schools

8. Davies, D. (2000). How to build partnerships that work. Principal 80(1) https://www.education.ne.gov/wpcontent/uploads/2017/07/Partnerships.pdf

9. Decker, Larry E. \& Associates. (1990). Developing Community Involvement in School-Family-Community Partnerships. Community Education: Building Learning Communities, pp. 4-8. National Community Education Association, Alexandria, VA.

10. DepEd Memorandum No. 53, s. 2020. “Joint Implementing Guidelines on the 2020 Brigada Eskwela and Oplan Balik Eskwela Relative to the COVID-19 Situation (Amending Thereby DepEd Memorandum No. 032, s. 2020 titled 2020 Brigada Eskwela Program Implementing Guidelines, and DepEd Memorandum No. 014, s. 2020 titled 2020 Oplan Balik Eskwela)". Department of Education, Philippines. https://www.deped.gov.ph/2020/05/28/dm-053-s-2020/

11. DepEd Order No. 24, 2020. "National Adoption and Implementation of the Philippine Professional Standards for School Heads." Department of Education, Philippines.

https://www.deped.gov.ph/2020/09/07/september-7-2020-do-024-s-2020-national-adoption-and-implementation-of-thephilippine-professional-standards-for-school-heads/

12. DepEd Order No. 12, 2020. "Adoption of the Basic Education Learning Continuity Plan (BE-LCP) for School Year 2020-2021 in Light of the COVID-19 Public Health Emergency." Department of Education, Philippines. https://www.deped.gov.ph/2020/06/19/june-19-2020-do-012-2020-adoption-of-the-basic-education-learningcontinuity-plan-for-school-year-2020-2021-in-the-light-of-the-covid-19-public-health-emergency/

13. DepEd Order No. 11, s. 2020. "Revised Guidelines on Alternative Work Arrangements in the Department of Education During the Period of State of National Emergency Due to COVID-19 Pandemic". https://www.deped.gov.ph/2020/06/15/do-011-s-2020

14. DepEd Order No. 40, s. 2015. “Guidelines on K to 12 Partnerships”. Department of Education, Philippines. https://www.deped.gov.ph/2015/08/28/do-40-s-2015-guidelines-on-k-to-12-partnerships/

15. De Villa, J.A., Manalo, F.K.M. (2020). Secondary Teachers' Preparation, Challenges, and Coping Mechanism in the Pre - Implementation of Distance Learning in the New Normal, pp.144 - 154.

16. Diedrich, I.M. (1987). Adopt-a-School Programs: A Descriptive Study in Selected Elementary Schools With Implications for the Building Principal. Thesis. The University of Illinois at Urbana-Champaign.

17. Epstein, J.L., Sanders, M. (2005). School-Family-Community Partnerships and Educational Change: International Perspectives https://www.researchgate.net/publication/225906701_School-Familyb_Community

18. Epstein, J.L. (1987). Epstein's Theory Of Overlapping Spheres Of Influence. https://www.coursehero.com/file/p32g4gsn/Epsteins-1987-1995-theory-of-overlapping-of-spheres-of-influence

19. Facilities 450mm Consortium. (2021). 8 Benefits of Technology in the workplace. https://f450c.org/8-benefits-of-technology-in-the-workplace/\#google_vignette

20. Guo, Y.-R., Cao, Q.-D., Hong, Z.-S., Tan, Y.-Y., Chen, S.-D., Jin, H.-J., . . Yan, Y. (2020). The origin, transmission and clinical therapies on coronavirus disease 2019 (COVID-19) outbreak - an update on the status. Military Medical Research, 7(11), https://doi.org/10.1186/s40779-020-00240-0.

21. Handog, M.C. (2020). The Pandemic is Reshaping Education, Here's How the Philippines is Coping. https://www.rappler.com/brandrap/tech-and-innovation/coronavirus-reshaping-distance-learning-educationphilippines

22. Harvard Family Research Project. (2010). Partnerships for learning: Promising practices in integrating school and out-of-school time program supports. http://www.hfrp.org/publications-resources/browse-our-publications/partn

23. Josselson, R. (2007). The ethical attitude in narrative research. Fielding Graduate University Retrieved from: https://www.researchgate.net/publication/306151924_The_ethical_attitude_in_narrative_research

24. Knight, S.L. (1986). An Assessment of the Adopt-A-School Program Operational Practices and Principals' Perceptions of the Effectiveness of the Adopt-A-School Activities". ETD Collection for Tennessee State University. Paper AAI8802616.https://digitalscholarship.tnstate.edu/dissertations/AAI8802616 
EPRA International Journal of Environmental Economics, Commerce and Educational Management

Journal DOI: 10.36713/epra0414 |ISI I.F Value: 0.815|SJIF Impact Factor (2021): 7.743 ISSN: 2348 - 814X

Volume: 9 | Issue: 1 | January 2022

25. Konu, A. and Rimpela, M. (2002). Well-being in Schools: A Conceptual Model. Health Promotion International, Volume 17, Issue 1, March 2002, Pages 79-87, https://doi.org/10.1093/heapro/17.1.79

26. LaRocque, N. (2008). Public-Private Partnerships in Basic Education: An International Review. Adopt-a-School Foundation: Programme ManagerCfBT Education Trust. (C) CfBT copyright May 2008

27. Llego, M.A. (2020). DepEd Resources. 2020 DepEd Adopt-A-School Program (ASP) Toolkit. https://www.teacherph.com/deped-adopt-a-school-program-asp-toolkit/

28. Lisud, R.M. (2021). New Normal of School Leadership. St. Francis Elementary School. depedbataan.com Publications http://www.depedbataan.com/resources/4/new_normal_of_school_leadership.pdf

29. Little, P. (2011). School-Community Learning Partnerships: Essential to Expanded Learning Success retrieve from:https://www.expandinglearning.org/expandingminds/article/school-community-learning-partnerships-essentialexpanded-learning-success

30. Little, P. (2011). Expanded learning opportunities in Washington state: Pathways to student success. http://www.schoolsoutwashington.org/UserFiles/File/ELO\%20Policy\%20Brief

31. Malik, A. (2010). Public-private partnerships in education: lessons learned from the Punjab Education Foundation Mandaluyong City, Philippines: Asian Development Bank. https://www.adb.org/sites/default/files/publication/27494/ppp-education-punjab.pdf

32. National School Public Relations Association (2006). How Strong Public Relations Contributes to Student and School Success: Parent and Family Involvement. 15948 Derwood Road Rockville, Maryland 20855 301-519-0496 www.NSPRA.org https://www.nspra.org/files/docs/Strong_Communication_Students_School_Success.pdf

33. Neubauer, B.E., Witkop, C.T. \& Varpio, L. How phenomenology can help us learn from the experiences of others. Perspect Med Educ 8, 90-97 (2019). https://doi.org/10.1007/s40037-019-0509-2S

34. Ossiannilsson, E. (2020). The New Normal: Post COVID-19 is About Change and Sustainability. Near East University Journal of Education Faculty (NEUJE) [volume 4, issue 1] file:///C:/Users/User/Downloads/THE_NEW_NORMAL_POST_COVID_19_IS_ABOUT_CH.pdf

35. Patton, M. (1990). Designing Qualitative Studies PURPOSEFUL SAMPLING. Qualitative evaluation and research methods (pp. 169-186). Beverly Hills, CA: Sage. https://www.scribd.com/document/187549394/Patton-1990Purposeful-Sampling

36. Polkinghorne, D.E. (2005). Language and Meaning: Data Collection in Qualitative Research. Journal of Counselling Psychology, 52, 137-145. https://www.scirp.org/(S(351jmbntvnsjt1aadkposzje))/reference/ReferencesPapers.aspx? ReferenceID $=1568791$

37. Republic Act No. 8525. (1998). "Adopt-a-School Act of 1998.

38. Tenth Congress of The Philippines, Metro Manila, Philippines. February $14, \quad 1998$. https://www.lawphil.net/statutes/repacts/ra1998/ra_8525_1998.html

39. Sheninger, E. (2015). Transforming Your School With Digital Communication. Volume 7, Number 7. http://www.ascd.org/publications/educational-leadership/apr15/vol72/num07/Transforming-Your-School-with-DigitalCommunication.aspx

40. Soper, S. (2017). 4 Ways for Administrators to Foster Positive Relationships with Their Teachers. Teach.com https://teach.com/blog/4-ways-for-administrators-to-foster-positive-relationships-with-their-teachers/ 